\title{
Ecofeminism Perspective on the Role of Women Concerning Nature in Miyori No Mori Anime
}

\author{
Fajria Noviana $^{1 *}$, Budi Mulyadi², and Yuliani Rahmah ${ }^{3}$ \\ ${ }^{1}$ Universitas Diponegoro, Fakultas Ilmu Budaya, Jl. Prof. Soedarto, Semarang, Indonesia \\ ${ }^{2}$ Universitas Diponegoro, Fakultas Ilmu Budaya, Jl. Prof. Soedarto, Semarang, Indonesia \\ ${ }^{3}$ Universitas Diponegoro, Fakultas Ilmu Budaya, Jl. Prof. Soedarto, Semarang, Indonesia
}

\begin{abstract}
This paper examines the role of women in their relation to nature as represented in the anime Miyori no Mori through an ecofeminist perspective, considering that men in the patriarchal world often exploit women and nature. Especially in Japan, where this anime came from, its gender relations remain deeply patriarchal and unequal until now. This study used the qualitative paradigm and ecofeminism approach. Data were obtained from data sources in the form of an anime entitled Miyori no Mori. We chose this anime because it represents an issue about women as well as an issue about nature and the environment, two things that will never stop being discussed. The data taken are events, objects, and dialogues related to the main female character and nature. Data analysis was carried out using interpretive qualitative discourse analysis with an eco-feminist approach that focuses on the subordination of women and the subordination of nature to the interests of humans (men). In addition, a semiotic perspective is also used to interpret the signs contained in the scene image. This research succeeded in finding two things, namely (1) women's resistance to patriarchal power over nature and women; and (2) women's deconstruction of patriarchal power over nature and women.
\end{abstract}

\section{Introduction}

The dichotomy of men vs. women often harms women in patriarchal cultures because women positioned after men in this dichotomy are continuously marginalized, subordinated, and underestimated. Patriarchal society places women as objects and gives them a role not far from cooking, cleaning, and procreating. These roles are in the domestic sphere, as pointed out by Sherry B. Ortner about women's primary place, as it remains in the domestic sphere [1]. Ortner also mentioned that woman is being identified with, or symbolically associated with, nature, as opposed to man, who is identified with the culture [2]. At this point, we can see that the dichotomy of culture vs. nature is just as same as of men vs. women.

Because they are placed as objects, women often receive unfair treatment from society. Marginalization, subordination, stereotyping, gender-related violence, and double workload are types of gender injustice that often afflict women [3]. In a society that adheres to a patriarchal culture, such as the Japanese, these various gender injustices can be found in

* Corresponding author: fajria.noviana@live.undip.ac.id 
everyday life. Even in fairy tales for children, the aroma of patriarchal hegemony in Japan is very pronounced, so it is not surprising that Japanese gender relations remain deeply patriarchal and unequal until now [4].

Not much different from women, children often become the targets of social oppression because the world we live in tends to be adult-centred that better serves the interests of influential adults than the most basic survival needs of youth [5]. Consequently, children are often denied appropriate care and attention, social participation, and respect. Many children experience a sense of confusion, alienation, and despair in response to an emotional characteristic of childhood in modern and postmodern societies. On the one hand, children are asked to do adult responsibilities that are not of their choosing, e.g., take care of younger siblings when parents are working. On the other hand, children are systematically excluded from meaningful social and political participation. Children in adult-centered societies are subjected to forms of discrimination similar to those experienced by women under patriarchy. Perceived as subordinates, children, like women, are consigned to the margins of history. Their activities are restricted to the private domain, such as family, school, and neighbourhood. Consequently, their social presence and social contributions remain largely unacknowledged [5].

On the contrary, several Japanese literary works tell about the heroic actions of children concerning nature and the environment. One of them is an anime entitled Miyori no Mori or "Miyori's Forest" [6]. This anime tells the story of a $6^{\text {th }}$-grade elementary school girl named Miyori, who attempts to stop constructing a dam in Komori village where her grandparents live, with the help of some of her school friends. Miyori herself comes from Tokyo, but after her parents separated, she lived with her grandparents in the countryside. The dam that will be built is planned to use up the area of Komori village and the forests and lakes around the village, which can jeopardize the environment and the creatures that live there. In short, this anime tells the story of an effort to save the environment that a little girl leads.

We intended to study this Japanese anime with an ecofeminism perspective, considering that Japanese gender relations remain deeply patriarchal and unequal until now. However, it has literary works that emphasize women's struggles, even a little girl, concerning nature. The perspective of ecofeminism here refers to the feminist awareness that sees human oppression against nature, not to the nurturing nature of women constructed by a patriarchal culture. This study aims to describe the role of women in their relationship with nature represented in the anime Miyori no Mori through the perspective of ecofeminism, considering that women and nature usually become the objects of unfair treatment and exploitation by men in the patriarchal world.

The term ecofeminism was first mentioned by Françoise d'Eaubonne in his book Le Féminisme ou La Mort or "Feminism or Death" which was published in 1974 [1]. In D'Eaubonne's book, it is argued that there is a relationship between the domination of nature and domination of women because ecofeminism has the basic assumption of a logic of domination that causes oppression of women and nature. Meanwhile, according to Karen J. Warren, ecofeminism is a general term for the relationship between "women-other human Others-nature." Women are interconnected with other humans, humans as "Others", and nature. Humans as "Others" refers to the issue of domination, exploitation, and colonization of certain groups that have subordinated status [7]. According to Mayer [8], the ecological issue in ecofeminism is awareness of resistance to the frame of mind that humans are superior to nature as a justification for the practice of domination and destruction of nature.

Research on ecofeminism studies of literary works has been done quite often. However, according to Nugraha et al. [8], some of them only collect parts of the literary works studied that relate to the character of women when they interact with nature. He and his colleagues researched a poem entitled Isteri by Darmanto Jatman with an eco-feminist perspective. As a result, it was found that the equivalent of women to goddesses and nature (earth) as mothers 
and as part of the male self in the Javanese view of life is different from the Western view of life regarding the earth as a source of worldly prosperity.

The following research with the research object in the form of a novel is about the deconstruction strategy of the patriarchal power over nature, the environment, and women in Ayu Utami's three novels with an ecofeminist approach [9]. In this study, it was found that some characters from the three novels struggled against patriarchal power over nature, the environment, and women. The form of resistance carried out by some characters in the three novels studied is in line with ecofeminism thinking and is a deconstruction strategy against patriarchal power over nature, the environment, and women. Meanwhile, other research that still uses novels as the object of research is the relationship between nature and women, as reflected in the novel Aroma Karsa by Dewi Lestari. As a result, it is found that this novel represents the exploitation of nature by humans that goes hand in hand with women's oppression [10].

What distinguishes these studies from this paper lies in the data sources used. The data of this research comes from digital literary works in Japanese anime, while the previous research data comes from written literary works in novels and poems. Because of the audio-visual type, a semiotic approach is also needed in the analysis to interpret the signs that appear in the form of sounds and images, which cannot be found in written literary works.

\section{Method}

This study used the qualitative paradigm and ecofeminism approach. The data were obtained from data sources in the form of an anime entitled Miyori no Mori released in 2007. This anime was chosen because it represents environmental issues and issues about women, two things that will never stop being discussed. The data taken are in the form of events, objects, and dialogues related to the main female character and nature, classified according to their types.

Data analysis was carried out using interpretive qualitative discourse analysis with an ecofeminist approach that focuses on the subordination of women and the subordination of nature to the interests of humans (men). In addition, some data was analyzed using a semiotic approach to determine the meaning of the signs contained in the data in the form of images. With these two approaches, the role of women in their relationship with nature represented in this anime can be described.

\section{Results and Discussion}

By using an ecofeminism perspective to describe the role of women in their relationship with nature as represented in the anime Miyori no Mori, this research succeeded in finding two things, namely (1) women's resistance to patriarchal power over nature and women; and (2) women's deconstruction of patriarchal power over nature and women. These two things were pioneered by Miyori, a $6^{\text {th }}$-grade elementary school girl. The explanation of the two findings is as follows.

\subsection{Women's resistance to patriarchal power over nature and women}

The patriarchal power that women in this anime oppose is the view of belittling women in various things that are done by men; construction of a dam by some corporation from the city that jeopardize the villagers and all creatures living in the Komori village forest; and efforts to destroy the golden eagle, the endangered and protected animal. 
Men's disdainful view of women can be seen when bounty hunters accidentally run into Miyori in the forest and immediately perceive Miyori as a weak little girl who will only interfere with their duties. Likewise, Miyori's schoolmate at the Komori village elementary school, whose name is Daisuke has this disdainful view about Miyori. Daisuke had considered Miyori a selfish, arrogant, spoiled child, and other condescending assumptions, just because Miyori came from a big city. Even so, that thought gradually turned to respect as Daisuke got to know Miyori more closely.

In ecofeminism, corporations are considered agents of oppression against nature, which is then associated with patriarchal oppression against women. For Ynestra King, the sense of responsibility of women towards the earth and future generations is shown by opposing patriarchy which destroys women and destroys nature [11]. King's opinion is in line with Miyori's resistance to the corporation that tries to destroy the golden eagle in Komori village through hunters so that no one gets in the way of the dam construction plan. The hunters and field surveyors who came to that countryside were all male. This further confirms the perspective of ecofeminism regarding corporations as oppressors of nature and men as actors of oppression against women.

\subsection{Women's deconstruction of patriarchal power over nature and women}

In a patriarchal culture, the male vs. female dichotomy tends to be harmful to women. Women are culturally constructed as not prioritizing logic, emotionally, weak, identified with nature and domestic by society. Meanwhile, men are constructed highly different from women; almost everything synonymous with strength resides in men. However, these dichotomies are deconstructed through the characters of Miyori and her grandmother.

Table 1. Dichotomies are found in Miyori no Mori.

\begin{tabular}{|c|c|c|c|}
\hline \multicolumn{2}{|c|}{ First mentioned } & \multicolumn{2}{c|}{ Second mentioned } \\
\hline Men & $\begin{array}{c}\text { Logic, rational, strong, } \\
\text { culture, public sphere }\end{array}$ & Women & $\begin{array}{c}\text { Illogical, emotional, } \\
\text { weak, nature, domestic } \\
\text { sphere }\end{array}$ \\
\hline City & Modern, advanced & Village & Traditional, outdated \\
\hline Modern & Represented by dam & Traditional & Represented by forest \\
\hline
\end{tabular}

Miyori is shown as a strong little girl, both physically and psychologically. We can see that Miyori is relatively physically strong when bullier Daisuke threw Miyori's back with a volleyball, and she threw it back to Daisuke that made him fell to the ground. Psychologically, we can see that little Miyori did not fall into a depression even though her parents were separated. Meanwhile, her role as a forest guardian in Komori village that she inherited from her grandmother also shows that Miyori is a strong little girl, both physically and psychologically.

Miyori deconstructed the idea about women who were constructed in the domestic sphere by appearing as a pioneer in the fight against the corporation that would build a dam in Komori village. Miyori's resistance has the support of her school friends (children) and her grandmother (woman), a group often neglected in a patriarchal and adult-centered world [5].

Meanwhile, although villages are considered less suitable than cities, villages provide more peace of life than cities. The peaceful atmosphere of the village made Miyori insist on staying in the village with her grandparents, even though Miyori's mother came to pick her up to stay in Tokyo again. 
Table 2. Stereotypes against women deconstructed in Miyori no Mori.

\begin{tabular}{|c|c|c|c|}
\hline \multicolumn{2}{|c|}{ Original ones } & \multicolumn{2}{c|}{ Deconstructed ones } \\
\hline Witch & Old women, ugly, evil & Witch & $\begin{array}{c}\text { Old and young lady, } \\
\text { friendly face even } \\
\text { beautiful, kind-hearted }\end{array}$ \\
\hline Women & Nurture as nature & Women & Nurture as consciousness \\
\hline $\begin{array}{c}\text { Patriarchal } \\
\text { logic }\end{array}$ & $\begin{array}{c}\text { Nature and everything } \\
\text { in it as a source of } \\
\text { capital }\end{array}$ & $\begin{array}{c}\text { Human } \\
\text { logic }\end{array}$ & $\begin{array}{c}\text { Nature and everything in } \\
\text { it as living things }\end{array}$ \\
\hline
\end{tabular}

The stereotype of a witch is that an evil witch is deconstructed through Miyori's grandmother, who is considered a white witch by the villagers of Komori, one of which is because of her ability to cure various diseases that the villagers suffer from with herbal potions. Miyori's grandmother plays a role as a forest guardian in Komori village, who will pass her role on to Miyori according to the will of the goddess who lives in the cherry trees in the forest of Komori village, who acts as the forest guardian.

The nature of women as nature's nurturer, which is the result of patriarchal construction, was deconstructed by Miyori. Her ignorance of nature and the environment has turned into awareness to protect the Komori village forest from the destruction caused by the dam developer. This awareness is in line with the perspective of ecofeminism which emphasizes women's consciousness, not nature. Thus, the patriarchal logic that views nature and everything in it as a source of capital [12] has been successfully deconstructed into a common logic that nature and everything in it is living things that must be preserved.

\section{Conclusions}

The perspective of ecofeminism that sees human oppression against nature has raised awareness to protect, care for, and conserve nature in the anime Miyori no Mori. The exploitation of nature by humans symbolizes the exploitation of women by men. The struggle to save nature in the form of Komori village forest may be an effort to save traditional Japanese values from the modernization symbolized by building a dam. Miyori, who has modern values (coming from Tokyo) and traditional values (coming from the countryside and descending from a white witch), is the perfect mediator for this effort. Through this anime, the author tries to invite his audience to criticize the power of patriarchy and pay attention to the preservation of nature and the environment, the harmony of man and nature, and gender equality.

We want to thank the Faculty of Humanities, Universitas Diponegoro, for their support in preparing this paper, which was funded by DIPA funds for the 2021 fiscal year.

\section{References}

1. R. Tong, Feminist thought: A More comprehensive introduction, (Westview Press, 2014)

2. S. B. Ortner, Is female to male as nature is to culture?, Fem. Stud., 1, 5-31 (1972)

3. M. Fakih, Analisis gender dan transformasi sosial, (Pustaka Pelajar, 2013)

4. F. Noviana, Gender inequality in Japanese fairy tales with female main character, in The 5th International Conference on Energy, Environmental and Information System (ICENIS 2020), 202, 07053 (E3S Web of Conferences, 2020) 
5. R. Kurth-Schai, Ecofeminism and children, in Ecofeminism: Women, Culture, Nature (ed. Warren, K. J.) 193-212 (Indiana University Press, 1997)

6. N. Yamamoto, Miyori no Mori, (Fuji Television Network, 2007)

7. K. J. Warren, Ecofeminist Philosophy: A Western Perspective on What It is and Why It Matters, (Rowman \& Littlefield Publishers, 2000)

8. D. Nugraha, S. Suwondo, S. Suyitno, Pembacaan berperspektif ekofeminisme atas sajak "Isteri" karya Darmanto Jatman, Kandai, 16, 77-95 (2020)

9. W. Wiyatmi, M. Suryaman, E. S. Sari, Dekonstruksi terhadap kuasa patriarki atas alam, lingkungan hidup, dan perempuan dalam novel-novel karya Ayu Utami, Litera, 15, 281291 (2016)

10. N. P. Giriani, Relasi alam dan perempuan dalam novel aroma karsa karya dewi lestari: Kajian ekofeminisme, in Seminar Nasional Bahasa, Sastra, dan Seni (Sesanti) 2019, 273285 (2019)

11. M. Mies, V. Shiva, Ecofeminism, (Zed Books Ltd., 2014)

12. D. Candraningrum, Ekofeminisme dalam tafsir agama, pendidikan, ekonomi, dan budaya, (Jalasutra, 2013) 